\title{
Missed connections: Pomeranian Medical University's efforts to join circulation- of-knowledge networks in the pre-Thaw Cold War times (1948-1956)
}

\begin{abstract}
The paper presented is a case study discussing the difficulties a newly established medical school had to face when trying to build itself into existing circulation-of-knowledge networks during the Stalinist period, on the example of Pomeranian Medical University of Szczecin (PUM), founded in 1948. Based on the perusal of documents from the years 19481956 preserved in PUM's Archives, the paper analyses whether and to what degree the school was able to meet a number of criteria essential for becoming a relevant node in the network of knowledge, especially in trans- and international contexts. The criteria discussed include: access to appropriate infrastructure and resources; personnel qualified, willing and able to generate and circulate knowledge; sufficient decisional autonomy; support from power centers; and connectedness with the existing networks. Szczecin's post-1945 status in Poland and Europe is highlighted as a major factor behind the Stalinist state government's simultaneous reluctance to tackle PUM's urgent infrastructural and personnel deficits, and willingness to use PUM as an instrument of political propaganda.

Keywords: Pomeranian Medical University, circulation of knowledge, Stalinism.

In medicine, similarly to other fields of science/knowledge, ideas and practices are constantly proposed, discussed, challenged, examined, framed and reframed, falling into, or out of, more or less widely accepted use.
\end{abstract}


This never-ending movement shapes, and is shaped by, networks connecting individual persons, communities, and institutions, on both local and global levels. ${ }^{1}$ Up till recently, studies on whether and how this circulation permeated the geopolitical divides of the Cold War Europe had been a "deficit field". ${ }^{2}$ This gap is now beginning to fill. ${ }^{3}$ The few already completed projects show that without the narratives about people and institutions from the Eastern side of the Iron Curtain, the picture of inter- and transnational circulation of medical knowledge in Europe after World War II is severely distorted. ${ }^{4}$ However, studies published so far either mention the pre-Thaw period in passing only, or omit it altogether. ${ }^{5}$ This might be caused by the presumption that in the times of vicious Stalinist terror, scholars and scholarly institutions of the Eastern Bloc were not allowed to engage in network-building endeavors reaching across the Iron Curtain, as these were ideologically unacceptable in the eyes of the almighty communist Party (in Poland's case: Polish United Workers' Party, henceforth PUWP). For the USSR, this premise is indeed supported by evidence, from both pre- and post-war period, of severe punishment inflicted upon Soviet scholars for embracing and defending concepts in biology, physiology, and clinical medicine condemned by the Stalinist regime as 'imperialist',

1 See, for example: Chandra Mukerji, "Science, Social Organization of," in International Encyclopedia of the Social \& Behavioral Sciences (2001):13687-13691.

2 Susan Gross Solomon, "East European public health and the Cold War. In search of circulation," Revue d'Etudes Comparatives Est-Ouest 1, no. 1 (2018): 7, doi:10.3917/ receo1.491.0007.

3 See, for example: the Reluctant Internationalists Project, directed by Jessica Reinisch at Birkbeck College, University of London in the years 2013-2017, http://www7. bbk.ac.uk/reluctantinternationalists/; Revue d'Etudes Comparatives Est-Ouest 1, no. 1 (2018; Special Report: Medicine and Public Health in Eastern Europe during the Cold War), https://www.cairn-int.info/journal-revue-d-etudes-comparatives-estouest-2018-1.htm; Dóra Vagha, Polio Across the Iron Curtain. Hungary's Cold War with an Epidemic (Cambridge UK: Cambridge University Press 2018), https://doi. org/10.1017/9781108355421, and Kateřina Lišková, "History of Medicine in Eastern Europe: Sexual Medicine and Women's Reproductive Health in Czechoslovakia, Poland, and Hungary," European Journal for the History of Medicine and Health 78, no. 1 (2021): 181-194, doi: https://doi.org/10.1163/26667711-78010029.

4 The Reluctant Internationalists: Final Report, http://www7.bbk.ac.uk/reluctantinternationalists/report/.

5 One of notable exceptions to this statement: Psychiatry in Communist Europe, ed. Sarah Marks and Mat Savelli (Houndsmill Basingstoke, Hampshire: Palgrave Macmillan, 2015). 
or 'capitalist'. ${ }^{6}$ However, the very existence of such examples indicates that even in the Soviet Union under Stalin's rule, the exchange of scientific knowledge with the West was at least attempted. For Poland in the Stalinist times (1944-1956) ${ }^{7}$, no studies have been published so far on whether, and to what extent, similar attempts were made in field of broadly construed medical sciences. What can be deduced from the existing publications, is that official scientific cooperation channels between Polish scholars and the West were blocked effectively, even in institutions previously well-connected to the international networks. ${ }^{8}$ The following case study discusses the obstacles a newly-established institutional actor from behind the Iron Curtain faced when making efforts to join networks of international circulation of medical knowledge. The institution in question is the Pomeranian Medical University (Pomorski Uniwersytet Medyczny, henceforth PUM), founded in 1948 in Szczecin. ${ }^{9}$

To gain legitimization as a relevant node in a scientific network, a "knowledgeable body" (either individual, or collective) needs to satisfy

${ }^{6}$ In the English-language literature, the case of scientists punished for opposing the state-supported Lysenkoism features most prominently; a less widely known case of artificial pneumothorax for pulmonary tuberculosis condemned by Stalin as 'aristocratic therapy' is a good example from the field of clinical medicine. Svetlana A. Borinskaya et al., "Lysenkoism Against Genetics: The Meeting of the Lenin AllUnion Academy of Agricultural Sciences of August 1948, Its Background, Causes, and Aftermath," Genetics 213, no. 1 (May 2019):1-12, doi:10.1534/genetics.118.301413; Igor J. Polianski, "Bolshevik disease and Stalinist terror: on the historical casuistry of artificial pneumothorax," Medical History 59, no. 1 (January 2015): 32-43, doi: 10/1017/mdh.2014.69.

7 For the discussion of introduction of, and the cut-off points for, Stalinism in Poland, see Anthony Kemp-Welch, ed., Stalinism in Poland (1944-1956) (London: Palgrave Macmillan UK, 1999).

8 See, for example: Ryszard Herczyński, Spętana nauka. Opozycja intelektualna w Polsce 1945-1970 (Warszawa: Wydawnictwo Naukowe Semper, 2008), 54-63, 83-97, and 135-144; Henryk Gaerner, "Głos w dyskusji po referacie Juliana Dybca 'Uniwersytet Jagielloński wobec stalinizmu 1945-1956”, Prace Komisji Historii Nauki PAU 3 (2001), 33, http://pau.krakow.pl/PKHN-PAU/pkhn-pau-III-2001-1. pdf; Michał Musielak, "Potencjał naukowy i dydaktyczny Akademii Medycznej w Poznaniu w latach 1950-1956", in Uniwersytet Medyczny im. Karola Marcinkowskiego w Poznaniu w latach 1950-2019. Michał Musielak, ed., Historia i luminarze nauki (Poznań: Wydawnictwo Naukowe UAM, 2019), 115.

9 The school's official name changed several times within the seventy years of its existence; for sake of simplicity and visibility, I made the decision to use PUM's present name throughout the paper. 
a number of conditions. These include access to appropriate infrastructure and resources; will, ability, and opportunity to generate new knowledge; sufficient autonomy in directing one's scientific endeavors; support (or at least, no obstacles) from decision-making power center(s); and connection to other nodes in the network, enabling both absorption of others' contributions, and effective transfer of one's own work. Through the analysis of documents preserved at the Pomeranian Medical University's Archives, I examine whether, and to what extent, PUM was able to meet these conditions in the first years of its existence. Unfortunately, I was not able to peruse the documents showing the establishment and early years of the school from the perspective of the state government - these, kept in Warsaw and undigitized, were out of my reach due to the COVID-19 pandemic restrictions. Thus, the power center's voice in this story features indirectly, through what was recorded in the protocols of gatherings held by the school's teaching and administrative bodies.

\section{Infrastructure and resources}

The German city of Stettin had no university, and thus, no medical faculty with its scientific, didactic, and clinical infrastructure. However, there was the Midwives' School for the Province of Pomerania, founded in the early $19^{\text {th }}$ century, and operating up till spring 1945; since 1931, the school was based in the modern and well-designed building hosting Landesfrauenklinik. ${ }^{10}$ Beside this facility, there were also: the municipal hospital, since 1879 located in Pommersdorf (now: Pomorzany) in the southern outskirts of the city, and designed as a miniature gardencity; the Bethanien, a hospital complex founded in 1866 by the influential Quistorp family and run by the Diakonissen (this was where surgical antisepsis was introduced in Stettin, as well as the first aseptic surgical theater was built); a specialist pediatric hospital founded as early as 1851, also run by the Diakonissen, and, in the years 1853-1894 directed by Dr. August Steffen, the founder and the first president of the German Pediatric Society; the Kückenmühler Anstalten, a long-term care facility established in 1863 for patients suffering from a range of then-incurable conditions (mostly neurological and mental, but also tuberculosis); and

10 Günther Köhler, "Die Geschichte der Landesfrauenklinik Stettin“, Stettiner Bürgerbrief no. 24 (1998), 40-52. 
a considerable number of smaller clinics, both public and private, dispersed throughout the city and its suburbs, including a district hospital in Frauendorf (now: Golęcino). ${ }^{11}$ In the late 1930s, a large military hospital was built from scratch in the north-western outskirts of the city; it opened in September 1939. ${ }^{12}$

During World War II, Stettin sustained heavy damage as one of the targets of Allied Bombing Offensive. ${ }^{13}$ On 26 April 1945, the city capitulated to the Soviet Army; its further fates remained undecided until 5 July, when it was officially made the part of the Republic of Poland, as Szczecin. The exact border between Poland and the Soviet Occupation Zone of Germany was only established in November 1945; until that moment, Szczecin was a nominally Polish city surrounded by foreign territories. Even after the borders had been drawn up, there was hardly any difference between the power the Soviet Union entertained in the Occupation Zone, and in Poland's "Recovered Territories" (as they were called in the propaganda of that period). In Szczecin, the Red Army held undivided control of the industrial district (including the harbor and the shipyards) up till the late months of 1947; the Polish administration was allowed to take the district over only after everything of any value had been dismantled and transported to the USSR, as spoils of war. ${ }^{14}$

Similarly, the Soviets had the upper hand in claiming Szczecin's medical infrastructure for their purposes. Thus, they took the Bethanien and the military hospital, as the least destroyed. The former remained in their possession until 1992. The latter, at first used as a temporary camp for German prisoners of war, was handed over to Polish Red Cross (Polski Czerwony Krzyż, henceforth PCK) in 1946. The 500-bed hospital,

11 Joanna Nieznanowska, "Worlds Unexplored: Medicine in Stettin, 1800-1945", in Explorations in Baltic medical history, 1850-2015, eds. Nils Hansson and Jonatan Wistrand (Rochester: University of Rochester Press, 2019), 71-79.

12 Marek Łuczak, "Szpital przy Unii Lubelskiej / Das Krankenhaus am Deutschen Berg," in Szczecin Pogodno- Łękno / Braunsfelde-Westend (Szczecin: Pomorskie Towarzystwo Historyczne, 2009), 116-117.

13 Jakub Ciechanowski, "Target Stettin: the Allied Air Forces over Stettin 1940-1945," Studia Maritima 25 (2012), 125-139.

14 Substantial parts of the port remained in unpaid lease to the USSR up till 1955. Ryszard Łangowski, Henryk Salmonowicz, "Gospodarka morska w estuarium Odry," in Dzieje Szczecina 1945-1990, ed. Tadeusz Białecki and Zygmunt Silski (Szczecin: Wydawnictwo $13 \mathrm{Muz}, 1998)$, 303-305. 
refurbished with the equipment almost entirely obtained from UNRRA, could admit first patients in spring $1947 .{ }^{15}$

Of the remaining facilities, the municipal hospital at Pomorzany was out of use due to heavy wartime damage and post-war devastation; the former Frauenklinik was taken over by the Polish Army and transformed into a military hospital; the pediatric hospital was changed into a general one, and taken over by the Ministry of Public Security. In the former Kückenmühler Anstalten, the main hospital for the new voivodeship was located, initially entirely devoted to the fight with infectious disorders (Wojewódzki Szpital Zespolony at Arkońska Street, henceforth WSZ). The hospital in Golęcino, up till November 1945 outside the administrative borders of Szczecin, initially served the remaining German population, and, in 1946, was made a communal hospital maintained by the municipality. ${ }^{16}$

The presence of functionable hospitals could not count without sufficient numbers of trained staff. Poland's wartime losses in qualified medical personnel were disproportionately heavy. In 1938 Poland had the population of thirty-five million, including 12,917 physicians, and 3,686 dentists; in 1946, it had twenty-four million inhabitants, 7,732 physicians, and only 1,581 dentists. ${ }^{17}$ With the political status of the western "Recovered Territories" not entirely certain, few qualified practitioners decided to settle there. In October 1945, only twenty-eight physicians were registered in Szczecin, compared to over 70 thousand inhabitants. ${ }^{18}$ By the end of 1948, the number of physicians grew to 132, while the city's population reached 140 thousand. Only twenty-three doctors were registered in the rest of the voivodeship, inhabited by nearly 800 thousand

15 Roman Turczynowski and Teresa Turczynowska, "Służba zdrowia miasta Szczecina w roku 1945," Szczecińskie Roczniki Naukowe - Nauki Medyczne 4, no. 2 (1989), 127-139.

16 Tadeusz Brzeziński, “Szpitalnictwo,” in Dzieje Szczecina 1945-1990, 623-625.

17 Losses among the nurses were seemingly less devastating (6.674 vs. 5.840), but this was due to substantial numbers of women who obtained informal, often incomplete, nursing training during the war, and were counted together with fully qualified nurses during the first post-war national census in 1946. Rocznik Statystyczny 1946 (Warszawa: GUS, 1947), 138.

18 Mikołaj Mucha, "Zarys rozwoju służby zdrowia w województwie szczecińskim w latach 1945-1965", in Dwudziestolecie medycyny polskiej na Pomorzu Zachodnim, ed. Edward Gorzkowski (Warszawa: PZWL, 1968), 14; Rocznik Statystyczny 1947 (Warszawa: GUS, 1948), 23. 
people. ${ }^{19}$ To satisfy the region's hunger for physicians, new cadres had to be trained locally, and on spot. Warsaw announced the decision to have PUM established on March 20, 1948. ${ }^{20}$ Prof. Jakub Węgierko was appointed as Rector of the new school, with Prof. January Zubrzycki as Pro-Rector, and Dr. Czesław Murczyński as Dean; all three were to come to Szczecin from Lublin's Maria Curie-Skłodowska University, established in 1944. ${ }^{21}$

In the end of May 1948, experts from the Ministry of Health came to Szczecin to find out if, and under what conditions, the school could open in autumn. They agreed this was not possible for first-year courses: the city had no infrastructure adaptable for the purposes of pre-clinical teaching. However, opening fourth-year instruction for a limited number of students seemed realistic, under following conditions: transformation of the PCK hospital into PUM clinics of internal medicine, pediatrics, surgery, laryngology, ophthalmology, and dermatology (600-650 beds planned); reclaiming the former Frauenklinik from the Army, and placing the OB-GYN clinic there (360 beds planned); finding space for at least one lecture hall in the PCK hospital (the former Frauenklinik did have one, spacious and well designed); repairing an office building at Rybacka 1 and placing PUM's administration there; organizing an 80-bed student dormitory in a building at Niepodległości 30 (temporarily serving as PUM's headquarters); and preparing appropriate accommodations for professors and assistants (forty-five apartments needed) ${ }^{22}$. The facilities required for pre-clinical stage of medical and dental studies, clinical training for the final, fifth-year course of medicine, and clinical courses for dentistry, as well as a campus big enough to host the majority of PUM's predicted student community were proposed to be built step-by-step within five years from PUM's inauguration, with the fifth year of medicine opened for the first time in 1949/1950, and first-year courses in both medicine and

19 Janina Kiczak and Edward Gorzkowski, "Pomorska Akademia Medyczna w XX-leciu Pomorza Zachodniego", in Dwudziestolecie, 128-129; Rocznik Statystyczny 1948 (Warszawa: GUS, 1949), 22-24.

20 Cabinet Regulation of 20 March 1948, Dziennik Ustaw 1948, no. 21, item 145, http:// isap.sejm.gov.pl/isap.nsf/DocDetails.xsp?id=WDU19480210145.

21 “Kronika," Rocznik Pomorskiej Akademii Medycznej 1 (1951), 7.

22 Władysław Borawski, expertise for Ministry of Health concerning possible infrastructural arrangements for Physicians' Academy in Szczecin, 1 June 1948, Faculty Council Meetings (henceforth, FCM) 1948, sign. A107, [102], PUM Archives. 
dentistry inaugurated not sooner than October 1950. For the theoretical complex, a spacious, unfinished building at Słowackiego Street was nominated. For the clinics (1500 beds planned), the former municipal hospital at Pomorzany seemed the optimal solution. Firstly, it consisted of a number of independent buildings, which made the division of reconstruction work into manageable stages possible. Secondly, its reopening would create new hospital beds for the growing population of Szczecin and the voivodeship. For the campus, three options were proposed: the optimal, i.e., building it anew, close to the theoretical complex; the sub-optimal, i.e., renovating a group of houses in the vicinity of the hospital at Pomorzany; and the "least favorable", i.e., adapting former barracks at Ku Słońcu Street, requiring least investments, but distant from, and lacking public transport connection to, all teaching venues. ${ }^{23}$

By the time instruction began at PUM (in mid-November 1948), only two conditions listed in the expertise had been met: the PCK hospital's transformation into teaching clinics (Państwowy Szpital Kliniczny No. 1, henceforth PSK1), and the installment of the Rectorate at Rybacka. Against promises from the Ministry of Health, the Ministry of Defense did not want to let go of the former Frauenklinik. Thus, the OB-GYN clinic, reduced to 120 beds, was squeezed into PSK1, at the painful expense of other departments. As a result, ophthalmology clinic had to organize its operating theater in a bathroom, in "conditions failing to meet even the most primitive standards". ${ }^{24}$ The problem was 'temporarily' solved by taking two rooms from the clinic of surgery and moving the operating theater there; this solution was in force up till the ophthalmology department moved to Pomorzany in $1964 .{ }^{25}$ Space deficit at PSK1 was aggravated by the fact that, apart from clinics listed in the expertise, other units had to be placed there, including neurology clinic, departments of anatomic pathology, radiology, and microbiology, and a lecture hall. With all these additions, there was no space left for dermatology clinic, and it did not open until mid-March

23 Władysław Borawski, expertise for Ministry of Health concerning possible infrastructural arrangements for Physicians' Academy in Szczecin, 1 June 1948, Faculty Council Meetings (henceforth, FCM) 1948, sign. A107, [97-101], PUM Archives.

24 Prof. Witold Starkiewicz (ophthalmology) on situation in his clinic, 17 October 1948, FCM 1948, sign. A107, PUM Archives.

25 Julian Gryczuk, "Kronika Pomorskiej Akademii Medycznej za 1964 r.” Rocznik Pomorskiej Akademii Medycznej 11 (1965), s. 17. 
1949. ${ }^{26}$ For the first semester, theoretical teaching was the only option possible not just for dermatology but for obstetrics and gynecology as well. ${ }^{27}$ The OB-GYN clinic did finally move to the military hospital (in July 1949), but was a guest there, and not a very welcome one. ${ }^{28}$

The academic year of 1949/50, with two years of instruction planned, was expected to be doubly as challenging. There was no space left in PSK1 to open new facilities required for fifth-year courses in psychiatry, forensic medicine, and infectious diseases. While the latter could, and would, be taught in WSZ, no place in Szczecin and its surroundings existed where the former two could be carried out. The Ministry of Health solved this problem by assigning courses in forensic medicine and psychiatry to the department of anatomic pathology, and the neurology clinic, respectively. Similarly, fifth-year instruction in internal medicine, pediatrics, surgery, and OB-GYN was to be carried out in the clinics already in charge of the fourth-year training. ${ }^{29}$ To the faculty's dismay, however, the Ministry decided to have first-year courses for both medicine and dentistry opened, too; this decision was announced in April 1949. The Faculty's appeals, explaining the absolute non-existence of infrastructure required for pre-clinical teaching, fell on deaf ears. The opening of first-year courses in October 1949, the Ministry informed, was "to be treated as a task of highest national and political priority". ${ }^{30}$ Thus, the decision was made to use five rooms in the Rectorate building as the venue for firstyear courses in biology, histology, physics, medical propaedeutics, and foreign languages, as well as fifth-year courses in hygiene and epidemiology,

26 Dean Murczyński's communication, 11 May 1949, FCM 1949, sign. A108, PUM Archives.

27 Information on courses in OB-GYN and dermatology, 17 October 1948, FCM 1948, sign. A107, PUM Archives.

28 In February 1982, the clinic was forced out of the military hospital without prior notice, and had to find a place somewhere else, overnight. It returned to PSK1, this time taking space designed for outpatient clinics, and stayed there up till 2007, when it moved to its current location in Police. Sławomir Świderski and Elzbieta RoninWalknowska, "Klinika Medycyny Matczyno-Płodowej”, in Trylogia 60-lecia PAM, ed. Ireneusz Kojder (Szczecin: Wydawnictwo PAM, 2008), 3:267.

29 Notably, no additional teaching posts were created in these clinics. Brief communication, 22 June 1949, FCM 1949, sign. A108, PUM Archives.

30 Conference with the Ministry of Health delegation and Szczecin's municipality, Szczecin 29-30 April 1949. Administrative conferences 1949, sign. A244, 1, PUM Archives. 
propaedeutics of dentistry, and military training. ${ }^{31}$ Having no theater for didactic demonstrations and burdened with the additional task of teaching forensic medicine, the department of anatomic pathology could not stretch to hold descriptive anatomy for the predicted 200 first-year students. Thus, building the facilities for anatomy and chemistry, as well as preparing the venue appropriate for clinical dentistry training, were given priority. As soon as these problems would have been solved, the government's delegates declared, there would be funding for psychiatry, forensic medicine, and pathologic anatomy. ${ }^{32}$ The Ministry promised enough money for the construction work to be completed on time, while the municipality pledged to provide suitable accommodations for PUM's new professors and assistants. However, the initial plan to have the unfinished building complex at Słowackiego adapted for all the pre-clinical departments was abandoned as "too costly"; instead, the Ministry decided to place anatomy and chemistry in the former municipal hospital at Pomorzany. ${ }^{33}$ Unsurprisingly, this project did not go as planned. Only part of money promised was delivered. ${ }^{34}$ Neither the Ministry-assigned architect nor the construction company provided by the municipality had any experience in raising buildings designed for scientific research and didactics; thus, the chemistry laboratory was built without ventilation system suitable for the attachment of fume hoods. ${ }^{35}$ Because of huge delays, up till March 1950, chemistry was taught theoretically only, at the Rectorate. ${ }^{36}$ Anatomy department opened only one month past deadline, but struggled with inadequate equipment (the lack of telephone line was especially painful, as it severely impeded the obtaining of cadavers for didactic dissections). ${ }^{37}$

31 Conference with the Ministry of Health delegation and Szczecin's municipality, Szczecin 29-30 April 1949. Administrative conferences 1949, sign. A244, 1, PUM Archives, 2.

32 Ibid., 3.

33 Ibid., 4-6.

34 Information on construction delays at Pomorzany, 15 March 1950, FCM 1950, sign. A109, PUM Archives.

35 This was the reason why, in 1951, PUM made efforts to have another building adapted for the departments of chemistry and biochemistry, and use the existing premise as a temporary venue for dentistry clinics. Infrastructure Committee meeting, Szczecin 12 October 1951, FCM 1951, sign. A110, PUM Archives.

3650 lat $w$ zawodzie lekarza, 85.

37 Information on shortages experienced by the department of anatomy, 13 December 1951, FCM 1951, sign. A110, PUM Archives. 
In the years to follow, similar scenario repeated time after time: PUM's authorities did what they could to secure the state's support for infrastructural investments the school required to meet its duties towards students and patients, while the government either insisted on PUM to manage without what it needed, or gave less than promised. This, it should be noted, was largely due to deep economic crisis the entire country struggled with in the post-war times. However, compared to other medical schools organized from scratch at that time, Szczecin did seem to have been least subsidized. This might have resulted from insecurity around the city's geopolitical status in future. ${ }^{38}$ Inadequate infrastructural investments in the first years of PUM's existence had long-standing, negative impact on all its operations.

\section{People capable of producing and circulating knowledge}

"When we took this city, it had neither a university, nor a college; people used to spending their entire lives in lecture halls or laboratories did not come here to settle down. [Poland's] major cities, now demolished, did not move here. Unlike to Wrocław, our intelligentsia was not attracted to Szczecin." This is how a journalist who moved to Szczecin in 1947 described the city's social structure in the first post-war years. ${ }^{39}$ Physicians, especially those with scholarly ambitions, shared the intelligentsia's reluctance.

For the state government, finding people capable of jump-starting PUM proved difficult enough to reluctantly accept a number of candidates for clinical chairs despite their evident political incorrectness. Thus, January Zubrzycki was made the school's first Pro-rector because of his exceptional organizational skills, as well as the status of "world-class expert in surgical gynecology". At the same time, he was tagged "a conscious reactionist, hiding his actual political views behind leftist, often exaggerated,

38 The border treaty between West Germany and People's Republic of Poland had not been signed until December 1970. Ludwik Gelberg, "The Warsaw Treaty of 1970 and the Western Boundary of Poland," American Journal of International Law 76, no 1 (1982), 119-29. doi:10.2307/2200977.

39 Franciszek Gil, “Zapiski do reportażu o Szczecinie," in Szczecin Literacki: almanach, ed. Ireneusz Gwidon Kamiński (Szczecin, 1959), 205. 
declarations". 40 Zubrzycki was allowed to work in Szczecin until the OB-GYN clinic seemed well-settled; in 1952, he was moved to Gdańsk.

Similarly, Artur Chwalibogowski was given the chair of pediatrics because he was the only habilitated pediatrician in Poland willing to accept the post. Like Zubrzycki, he was recognized as a "masked reactionist" with "negative attitude towards present reality"; as such, he had worked in a municipal hospital in Cracow, unable to obtain academic employment suitable for his qualifications. ${ }^{41}$ He stayed at PUM for three years only. In 1951, he managed to transfer to the Silesian Medical Academy, where, unlike in Szczecin, he was given enough resources to organize pediatric training and care at the quality levels he found acceptable. ${ }^{42}$

Tadeusz Sokołowski was appointed the chair of surgery only after two other candidates had declined the offer. ${ }^{43}$ Not only was he the wrong kind of a socialist (with close bonds to Józef Piłsudski, and a history of active participation in the Soviet-Polish war of 1920 - on Polish side), but he served as a military surgeon in the Polish Armed Forces in the West during World War II, and stayed in England until he was offered a post in Szczecin. The communist authorities suffered him for his "exceptionally high qualifications" 44 , both organizational and professional, and because they could not find anyone nearly as qualified to replace him ${ }^{45}$.

PUM's first Rector, Jakub Węgierko, himself a renowned internist with internationally acclaimed research portfolio focusing around pathophysiology of diabetes mellitus and anti-inflammatory effects of insulin-induced hypoglycemia ${ }^{46}$, wanted Szczecin's medical school to present "possibly

40 Performance report [anonymous], 14 February 1951, Prof. Zubrzycki's personal files, sign. 1952/140, PUM Archives.

41 Performance report [anonymous], 15 February 1951, Prof. Chwalibogowski's personal files, sign. 1951/17, PUM Archives.

42 Maria Kempa, Prof. dr hab. n. med. Artur Chwalibogowski (1899-1994): twórca Śląskiej Szkoły Pediatrii (Katowice: Śląska Akademia Medyczna, 2006).

43 The post had been offered to Józef Gasiński (from 1949, chair of surgery at the Silesian Medical Academy) and Romand Drews (who later became professor of surgery in Poznań). Discussion concerning the candidates for the chair of surgery, 17 July 1948; 5 September and 5 October 1948, FCM 1948, sign. A107, PUM Archives.

44 Minister of Health to Prof. Tadeusz Sokołowski, Warsaw 10 April 1953, Prof. Sokołowski's personal files, sign. 1960/93, PUM Archives.

45 Witold Brzeziński, "Tadeusz Sokołowski i jego szkoła chirurgiczna” (PhD diss., PUM 1995), 77.

46 Mariola Lembas-Sznabel, "Profesor Jakub Węgierko i jego wpływ na rozwój światowej i polskiej diabetologii” (PhD diss., PUM 2006), 113-173. 
highest scientific level, so that it draws physicians and students from all over Poland". ${ }^{47}$ Unfortunately, tough reality thwarted Węgierko's plans. Securing good-quality candidates for PUM's clinical chairs proved challenging; the perspective of speedy professorial promotion did not outweigh the infrastructural deficits and inadequacies. Not only finding new clinical professors was problematic - keeping those already appointed was as difficult. Out of the nine trailblazing professors present in Szczecin at the beginning of academic year 1948/1949, only four were still there three years later: the ophthalmologist, Witold Starkiewicz; the laryngologist, Józef Taniewski; the radiologist, Czesław Murczyński, and the pathologist, Kazimierz Stojałowski. Węgierko himself moved to Warsaw in May 1950 to organize the Third Clinic of Internal Medicine. ${ }^{48}$ The chair he vacated in Szczecin remained unassigned until February 1951, when Edward Gorzkowski (Węgierko's former assistant from Lublin) agreed to take it. 49

In the years to follow, finding candidates willing to take charge of theoretical and clinical departments continued to be a difficult and frustrating task. The chairs of chemistry and biochemistry vacated for years, with teachers from Poznań (Kazimierz Kapitańczyk and Zdzisław Stolzmann, respectively) acting as emergency substitutes up till mid-1950s. ${ }^{50}$ No volunteers could be found to chair pharmacology, forensic medicine, and psychiatry. Repeatedly, candidates withdrew at the last moment (e.g., Kornel Gibiński for internal medicine ${ }^{51}$; Gabriel Brzęk ${ }^{52}$, Roman Wojtusiak ${ }^{53}$,

47 Rector Węgierko's opening speech to members of Faculty, 5 October 1948, FCM 1948, sign. A107, PUM Archives.

48 Information from the Ministry of Health on Prof. Węgierko's transfer to Warsaw, 17 May 1950, FCM 1950, sign. A109, PUM Archives.

49 PUM's administration authorized to urgently communicate with the Ministry of Health, re: Gorzkowski's nomination, 17 January 1951, Faculty Council meetings 1951, sign. A1951, PUM Archives.

50 Alicja Brożek, "Profesor Zdzisław Stolzmann (1906-1997) współtwórca poznańskiej szkoły chemii fizjologicznej" (PhD diss., Uniwersytet Medyczny im. Karola Marcinkowskiego w Poznaniu 2012), 67-70, https:/www.wbc.poznan.pl/dlibra/publication/349836/edition/285903/content.

51 Chair appointments, 11 October, 15 November, and 13 December 1950, FCM 1950, sign. A109, PUM Archives.

52 Chair appointments, 11 January, and 15 March 1950, ibid.

53 Chair appointments, 15 February, and 15 March 1950, ibid. 
and Wacław Ołtuszewski ${ }^{54}$ for biology; Andrzej Danysz ${ }^{55}$, Jan Venulet ${ }^{56}$, and Stanisław Kroszczyński for pharmacology57; and Jan Gallus for psychiatry $^{58}$ ).

Finding physicians willing to join the school's "auxiliary scientific forces" (the term used for all positions below the head of department) was equally problematic, especially that the salaries, compared to those received by doctors employed directly by hospitals, were lower by a third (when asked about this discrepancy, the Ministry explained bluntly that physicians in teaching posts at clinics were not intended to take actual care of patients). ${ }^{59}$ Junior assistant posts in theoretical departments were least attractive, therefore PUM received the Ministry's consent to have these assigned to fifth-year students. ${ }^{60}$ By the end of 1949, two-thirds of junior posts in PUM's eight theoretical departments were occupied by undergraduates, including nine out of nine at Anatomy, six out of six at Histology, and two out of two at Chemistry. However, students were employed as junior assistants in clinics, too: three each at Surgery and Neurology, two at Obstetrics, and one each at Dermatology and Internal Medicine. At the same time, senior teaching positions (i.e., assistant professor, and/or senior assistant) remained empty in the departments of Anatomy, Anatomic Pathology, Physics, Histology, Hygiene, Radiology, and Ophthalmology. In total, out of sixty-one junior assistant posts, thirty were occupied by students. PUM published these data, sending copies out to other medical schools, and governmental offices. ${ }^{61}$ Maybe because of the over-representation of students, and the actual number of vacating senior posts made

54 Chair appointments, 15 March and 19 April 1950, ibid.

55 Chair appointments, 11 October and 15 November 1950; 17 January and 14 February 1951, FCM 1950, sign. A109; and 1951, sign. A110, PUM Archives.

56 Chair appointments, 14 March 1951, FCM, sign. A110, PUM Archives.

57 Chair appointments, 20 June, 12 September, 17 October, and 14 November 1951, ibid.

58 Chair appointments, 14 February, 14 March, and 18 April 1951, ibid.

59 The Faculty urged PUM's management to inform the Ministry that all physicians working at PSK1, regardless of the mode of their employment, were equally engaged in both the teaching, and the medical services. Dean Murczyński's report on his correspondence with the Ministry of Health, 11 May 1949, FCM 1949, sign. A108, PUM Archives.

60 This was announced on 15 June 1949. FCM 1949, sign. A108, PUM Archives.

61 Skład osobowy i spis wykładów za rok akademicki 1948/49 oraz na rok akademicki 1949/50 (Szczecin: Pomorska Akademia Medyczna 1949). 
visible in the register, Warsaw postponed the printing of its second edition until 1960. By then, only six out of 300 assistant teaching posts divided between PUM's thirsty-seven departments were occupied by students - all in theoretical units. ${ }^{62}$

The fact that undergraduates made a half of PUM's initial "auxiliary scientific forces" had consequences for the production and circulation of knowledge. Even though some of the students showed genuine interest and talent in pursuing scientific questions and transferring knowledge to junior colleagues ${ }^{63}$, the majority took assistant posts just to have a source of income allowing them to continue studying. As a result, chairs of departments could not count on their junior assistants' active contributions to research they wanted to conduct. PUM's overall didactic results were affected, too. In the early 1950s, numbers of students failing examinations in the pre-clinical subjects were high enough to alarm the central government. Delegates of the Ministry of Health repeatedly came to Szczecin to explain in no uncertain terms that failure to produce numbers of physicians specified in governmental orders would jeopardize the goals of the SixYear Plan. ${ }^{64}$ Improvement was to be achieved through a number of actions, including increased supervision of learning process by students' organizations (effectively, the Party); and organizing obligatory teacher-lead revision courses for weaker students. At the same time, however, the Ministry had the initial two years of medicine and dentistry combined. This allowed to cut the number of teaching hours by half, but resulted in didactic groups counting sixty and more students. ${ }^{65}$

In the first years of PUM's existence, production and transfer of knowledge was also affected by the lack of effective communication between the school and the state's civilian and military administration. Physicians employed at PUM as auxiliary scientific forces were regularly either conscripted into the army or given administrative orders to take posts at medical

62 Skład osobowy Pomorskiej Akademii Medycznej na rok akademicki 1959/60 (Szczecin: Pomorska Akademia Medyczna, 1960).

63 Out of sixty students admitted to PUM in 1948, at least twenty obtained PhD titles; seven were habilitated, and four became full professors. 50 lat $w$ zawodzie lekarza, 49, 77, 88, 98, 105, 111, and 115 .

64 The Ministry's delegates attended extraordinary meetings of PUM's Faculty Council on 28 February and 9 October 1952, as well as 22 June 1953.

65 Discussion, re: didactic venues not big enough to hold lectures for medicine and dentistry students together, 11 January 1951, FCM 1951, sign. A110, PUM Archives. 
facilities outside Szczecin, without any prior notice. ${ }^{66}$ Sometimes, even students were sent to work in the voivodeship's outposts, regardless of academic year in progress ${ }^{67}$. This disrupted didactic work, and made any research difficult to plan and conduct.

Yet another problem was the disastrous lack of fully qualified nurses. Desperate to find and keep good nursing staff, professors of pediatrics and internal medicine were given permission to offer assistant teaching posts to nurses, thus being able to pay them higher, more attractive salaries. ${ }^{68}$ This did not affect didactics, as nurses were valued and praised as good teachers of practical skills. ${ }^{69}$ However, PUM's research potential suffered, as at the time discussed, physicians in Poland generally viewed nurses as unsuited to take active part in research endeavors. ${ }^{70}$

\section{Problems with autonomy and support from power center}

In Poland under Stalinist rule, autonomy was not an option for any public institution, including schools of all types and levels. The state's control over PUM's activities was overwhelming, and included, among others, the assignment of senior administrative and teaching posts, the directions and the pace of PUM's infrastructural growth, and the number and type of courses held. Because of PUM's location, the school was also used by the central government as a platform of political propaganda. This is how the school ended up with general Karol Świerczewski in its name.

66 Such incidents were reported and discussed at meetings on 12 January, 16 March, 12 October, and 14 December 1949, as well as 17 May and 14 June 1950. FCM 1949, sign. A108; and 1950, sign. A109. PUM Archives.

${ }^{67}$ In this case, the voivodeship's Health Department acted against the Ministry's directives, which was informed to the Faculty on 17 January 1951. FCM 1951, sign. A110, PUM Archives.

68 This decision was made on 24 November 1948 (pediatrics), 11 May 1949 (gynecology), and 25 March 1953 (internal medicine). FCM 1948, sign. A107; 1949, sign. A108; and 1953, sign A112. PUM Archives.

69 Interestingly, Prof. Starkiewicz (opthalmology) opposed this view, in discussion held on 25 February 1953. FCM 1953, sign. A112. PUM Archives.

70 Teresa Slosorz and Beata Fryc-Przybyłowska, "Z perspektywy 40-lecia akademickiego kształcenia pielęgniarek i położnych w Polsce," Polski Przegląd Nauk o Zdrowiu 45, no. 4 (2015): 280-87. http:/www.przeglad.amp.edu.pl/ uploads/2015/3/280_4_45_2015.pdf. 
Świerczewski, a Warsaw-born career communist who fought in the Red Army against Poland in the war of 1920, and whose incompetent command during the Spremberg-Torgau Offensive Operation in April 1945 caused enormous losses in the Soviet-controlled Second Polish Army, was killed in Bieszczady mountains in 1947, where he was in charge of Polish forces engaged in the domestic war with the Ukrainians. His death was used as a pretext to carry out Operation Vistula (Akcja "Wista", 19471950 ) in which the region's remaining local population, spared somehow in the 1944-1946 deportations into the USSR, was forcibly moved into Poland's northern and western territories. ${ }^{71}$ At the time PUM was inaugurated, nearly fifty thousand Ukrainians, Lemkos and Boykos tried to build their lives anew in the voivodeship of Szczecin. ${ }^{72}$ In November 1948, Rector Węgierko received information that "the Ministry of Health plans to rename Physicians' Academy in Szczecin as 'the General Karol Świerczewski Pomeranian Physicians' Academy', and expects that an appropriate petition will be produced". ${ }^{73}$ Węgierko presented the idea to other professors, who "supported it unanimously, and authorized the Rector to ask the Ministry for the approval". ${ }^{74}$ The request was sent promptly ${ }^{75}$, and the new name was made official in October 1949. ${ }^{76}$ The solemn presentation of Świerczewski as PUM's 'patron saint' took

71 Marek Jasiak, "Overcoming Ukraininan Resistance: the Deportation of Ukrainians within Poland in 1947", in Redrawing Nations: Ethnic Cleansing in East-Central Europe, 1944-1948, ed. Philip Ther and Ana Siljak (Lahnam, Md.: Rowman \& Littlefield, 2001). See also Rosa Lehman, "Struggling for peace: understanding Polish-Ukrainian coexistence in suotheast Poland", (PhD diss., University of Amsterdam 2009), https://dare.uva.nl/search?identifier=1079723f-f49c-4f05-8261$15 \mathrm{fbf} 3533 \mathrm{dea}$.

72 Roman Drozd, "Zasady rozmieszczenia ludności ukraińskiej na Ziemiach Odzyskanych w ramach akcji 'Wisła”, Stupskie Studia Historyczne 3 (1993), 106.

73 W. Titkow, Head of the Department of Cadres, Ministry of Health, to Rector Jakub Węgierko, Warsaw 15 November 1948 (K.III-3-11230/48), Establishment of Pomeranian Medical Academy, sign. A162. PUM Archives.

${ }^{74}$ Communication, re: school's Senate meeting, 24 November 1948, FCM 1948, sign. A107. PUM Archives.

75 Rector Jakub Węgierko to the Department of Cadres, Ministry of Health, Szczecin 29 November 1948, Establishment of Pomeranian Medical Academy, sign. A162, PUM Archives.

${ }^{76}$ Cabinet Regulation of 24 October 1949, Dziennik Ustaw 1949, no. 58, item 451, http:// isap.sejm.gov.pl/isap.nsf/DocDetails.xsp?id=WDU19490580451. 
place on 28 March 1950. Węgierko introduced him as chosen by PUM's students and professors, and stressed that Świerczewski, "heroic in life and death, and killed by a bandit's bullet", was a perfect role model for "socialist physicians". ${ }^{77}$ Thus, up till $19922^{78}$, PUM was stuck with a "paragon' whose only tangible connection to medicine was his alcohol-related hepatic cirrhosis, because the state wished to remind the region's new population who the boss was, and PUM's leaders did not dare to object. It is worthy of noting that no other medical school in Stalinist Poland was given a propagandist name.

Doctorates and, to some extent, habilitations were one of the few domains of academic life left to the discretion of the Faculty. In the years 1949-1951, two physicians were habilitated, and thirty-two obtained PhD titles at PUM. However, the right to carry out habilitations was lost with Prof. Węgierko's transfer to Warsaw, as this left Szczecin with Zubrzycki as the only full professor (eight chairs were extraordinary professors, and another eight were 'deputy professors'). In December 1951, a new Act on Higher Education was passed, styled after Soviet model. ${ }^{79}$ Habilitation was now removed altogether, while $\mathrm{PhD}$ title was replaced with a "candidate of science", its obtaining placed under central government's strict control. Up till 1958, only five persons employed at PUM received the titles of candidates of science. 80

Didactics were now to be the major focus of universities, while all activities related to scientific research, both individual and institutional, were to be centrally planned and supervised. In October 1952, the Ministry's delegate came to Szczecin and explicitly ordered PUM's Faculty Council to no longer discuss matters other than those referring to "quantitative and qualitative learning achievements", and the new, statecontrolled model of research work. PUM's professors were also told to

77 Rector Jakub Węgierko's speech, [28 March 1950], Establishment of Pomeranian Medical Academy, sign. A162. PUM Archives.

78 Act of 6 November 1992 on the name of Pomeranian Medical Academy, Dziennik Ustaw 1992 no 94, item 462, http://isap.sejm.gov.pl/isap.nsf/DocDetails. xsp?id=WDU19920940462.

79 Act of 15 December 1951 on higher education and workers of science, Dziennik Ustaw 1952, no 2 item 38, http://isap.sejm.gov.pl/isap.nsf/DocDetails. xsp?id=wdu19520060038.

80 Bolesław Górnicki, "Słowo wstępne," in Dziesięciolecie Pomorskiej Akademii Medycznej w Szczecinie 1948-1958 (Warszawa: PZWL, 1958), IV. 
read and discuss ministerial documents on centrally planned science, with detailed minutes of the discussion to be sent to Warsaw for inspection (as reporting of all faculty meetings to the Ministry was mandatory anyway, this order was clearly meant to remind PUM's professors of their subservience). ${ }^{81}$

In the three years to follow, all research work at PUM was expected to focus on "practical problems indicated by the Ministry of Health"; studies following the so-called Pavlovian paradigm were pushed for. ${ }^{82}$ Concrete results were expected, in terms of both realization of projects assigned, and production of publications. ${ }^{83}$ The Ministry expected its orders to be carried out to the minute, and did not care how this was to be achieved in the face of PUM's infrastructural, material, and personnel shortages. Warsaw's suggestions on how to use the scarce money were completely irrational, and yet, the Faculty was too intimidated to oppose them. For example, the Ministry of Health proposed that 150,000 out of PUM's 340-thousandzloty research budget for 1953 were used to organize the Pavlovian laboratory. Professors called-out to take this task refused explaining that they "had not been taught Pavlovism at university, but were learning it on their own; someone should be sent elsewhere first, to study the Pavlovian method properly". And yet, the sum suggested was secured in PUM's budget plan. ${ }^{84}$ At this time, the PSK1's central laboratory, "three years into its organization", was still waiting for the installation of sinks and fume cupboards, "operated with one micropipette, borrowed," and had no qualified personnel, because lab technicians could earn much more outside of PUM. This made laboratory-supported clinical research virtually impossible, as any analytic results obtained in such primitive conditions were "at risk of being fictional"; yet, despite appeals repeatedly sent to Warsaw, no improvement

81 Extraordinary conference with Prof. Ksawery Rowiński, head of the Department of Science and Education, Ministry of Health, Szczecin, 9 October 1952. The discussion ordered by Rowiński was held on 5 November. FCM 1952, sign. A111. PUM Archives.

82 Discussion, re: PUM's participation in centrally planned research projects, 5 November and 17 December 1952; ibid.

83 Starkiewicz: report on the realization of research plans for 1952, 25 February 1953, FCM, sign. A112. PUM Archives.

${ }^{84}$ Discussion between chairs of Neurology (Michał Jarema) and Physiology (Eugeniusz Miętkiewski), and PUM's Administrative Director, 5 November 1952, FCM 1952, sign. A 111. PUM Archives. 
could be achieved. ${ }^{85}$ Similarly, chair of Biology (Stanisław Zajączek) was unable to present a research plan for his department for 1953, because his requests for the "most basic equipment, like a thermostat" had been repeatedly ignored. ${ }^{86}$

\section{Connection to existing networks}

In the period discussed, PUM made first attempts to build itself into existing scientific networks. These efforts were shaped by the interplay between the trailblazing professors' personal connections, and the state government's power to actively affect the scope to which these connections could be used. Understandably, PUM's initial contacts with the world had a predominantly inward direction: with local resources severely lacking, the school depended on the influx of knowledge and 'knowledgeable bodies' from outside.

At first, access to medical journals was very limited. The only collection available in Szczecin at the moment of PUM's creation was a number of German periodicals, mostly gynecological (Archiv; Zeitschrift; Monatsschrift; Jahrbuch), but also general (Berliner klinische Wochenschrift; Münchener medizinische Wochenschrift; Klinische Wochenschrift), formerly the property of the Landesfrauenklinik. At the request of Prof. Sokołowski, the Royal Medical Society of London gifted PUM with volumes of Lancet and British Medical Journal from the years 1942-1948; when they arrived, the professors queued to read them. ${ }^{87}$ PUM subscribed to both journals, and they were the only Western titles the school was allowed to purchase. In 1949, efforts were made to have this number increased to ten 88 ; this proved impossible up till the Thaw.

Problems with attracting scholars to Szczecin's clinical and theoretical chairs have been mentioned earlier. A number of those who did decide to take senior teaching positions at PUM in the years 1949-1956, did so because of their previous working relationships with Szczecin's trailblazing

85 The state of the central laboratory at PSK1, 14 October 1953, FCM 1953, sign. A112. PUM Archives.

86 Prof. Zajączek's communication, 30 June 1953, ibid.

87 Communication, re: obtaining of medical journals from London, 8 November and 18 December 1948, FCM 1948, sign. A107. PUM Archives.

88 Prof. Stojałowski’s motion, 15 February 1949, FCM 1949, sign. A108. PUM Archives. 
professors. Thus, Zdzisław Heftman, from 1952 the head of PUM's Second Clinic of Surgery, was a post-graduate trainee at Sokołowski's Institute of Traumatology in Warsaw back in 1938; he came to Szczecin in 1950, at personal invitation from his former teacher. ${ }^{89}$ Stanisław Łuczyński, the first physician habilitated at PUM (in 1950), was Węgierko's senior assistant in Lublin, and came to Szczecin with his Chief; he stayed at PUM after Węgierko's transfer to Warsaw, and was in charge of Internal Clinic until Gorzkowski's arrival in 1951. ${ }^{90}$ Węgierko was also the reason for Adam Krechowiecki's agreement to leave Gdańsk and organize the Chair of Anatomy in Szczecin in 1949. They knew each other from Lublin, where in the years 1945-1946, Krechowiecki was a promising assistant at Anatomy. ${ }^{91}$

Poznań was a very important source of PUM's senior teaching cadres, especially for theoretical departments. Deputy and assistant professors affiliated there came to Szczecin to organize the departments of hygiene (Izabela Gądzikiewicz, 1949), histology (Jan Słotwiński, 1949), medical physics (Jan Konarski, 1949), physiology (Eugeniusz Miętkiewski, 1950), general pathology (Janusz Mąkowski, 1951), and pharmacology (Mieczysław Mazur, 1952). In 1955, after several years of acting as an informal head of PUM's department of biochemistry, Prof. Zdzisław Stolzmann delegated his senior assistant, Eugeniusz Łempicki, to take this chair. Many of these scholars maintained their connections with Poznań, and continued to do research there (one of the reasons for this was the lack of adequate infrastructure and equipment in Szczecin). Thus, Poznań contributed most prominently to PUM's budding research personnel potential.

Making Szczecin a venue for scientific meetings was another form of inviting knowledge to PUM, and establishing the city as a new node in Poland's scientific networks. The latter, one might think, would have encouraged the state government to promote Szczecin as a conference destination (as it was in case of Wrocław). Unfortunately, Szczecin had scarce resources (in terms of accommodations for guests, or lecture halls available), and, most importantly, was poorly connected with the rest of Poland.

\footnotetext{
89 Witold Brzeziński, "Heftman, Władysław Zdzisław," in Słownik biograficzny polskich nauk medycznych (Warszawa: Instytut Historii Nauki PAN, 2000), III/2:38-39.

90 Dziesięciolecie, 16.

91 Rector Węgierko's communication, 12 October 1949, FCM 1949. PUM Archives.
} 
After the first national medical conference held by PUM, the 1950 Congress of the Polish Gynecological Society, one of the participants complained that to get to Szczecin, the majority of guests had to spend two nights and days on trains. ${ }^{92}$ The next national conference took place in Szczecin in 1953 (Polish Surgical Society); two conferences were held in 1954 (Polish Medical Society of Radiology; Polish Pediatric Society), and in 1955 (Polish Society of Otolaryngology; Dental Surgery Section).

PUM made efforts to establish itself as source of knowledge, too. These were hindered by all obstacles discussed above, and PUM's own annals are a good example. The decision to have such a journal published regularly, with Sokołowski as chief editor and the Academy's most valuable doctoral dissertations as contents, was made in May 1950. ${ }^{93}$ By March 1951, enough material had been gathered for the first volume, but PUM was unable to obtain paper - it had to be granted by the Ministry of Health, which postponed the decision in spite of appeals sent repeatedly from Szczecin. ${ }^{94}$ Only in October 1951 the decision was finally made, and the first volume of PUM's Annals could be sent out to libraries, clinics, and schools in Poland and abroad (there were summaries in Russian and English). ${ }^{95}$ The delays with the second volume were even longer: scheduled for $1953^{96}$, it was actually printed only after the Thaw began in Poland, in late $1956^{97}$.

Textbooks published by PUM's professors are worthy of mentioning in this context, as one of the fields least affected by the ever-present limitations and deficits experienced in the period discussed. Because production of academic readers was one of the top priorities for the Ministry of Health, having a textbook printed was a comparatively straightforward matter. A number of highly sought-after, frequently re-issued textbooks were written by PUM's pioneers, e.g., a three-volume "Clinical Radiology"

92 Artur Ber, "Na marginesie XI Zjazdu Ginekologów w Szczecinie,” Służba Zdrowia, 20 June 1950.

93 Resolution on PUM's Annals, 17 May 1950, FCM 1950, sign. A109. PUM Archives.

94 Communications by PUM's Administrative Director, 14 March and 16 May 1951, FCM 1951, sign. A110. PUM Archives.

95 Sokołowski's information on PUM's Annals, 17 October 1951, ibid.

96 Communication, re: second volume of PUM's Annals, 18 June 1952, and 25 February 1953. FCM 1952, sign, A111, and 1953, sign. A112. PUM Archives.

97 Information, re: second volume of PUM's Annals, 19 September 1956, FCM 1956, sign. A115. PUM Archives. 
by Murczyński ${ }^{98}$, "Audiology" by Taniewski ${ }^{99}$, or a very popular "Human Anatomy Compendium" by Krechowiecki ${ }^{100}$.

Active cooperation with the world abroad, on the other hand, was very difficult. In 1950, PUM's professors were reminded that all kinds of contacts with foreign scientific bodies and institutions had to be reported in writing to the Ministry of Health. ${ }^{101}$ Before 1956, only three travels abroad were approved: in 1950, Starkiewicz went to GDR with a series of lectures; in 1954, Miętkiewski travelled to Moscow and Leningrad to learn the ropes of 'Pavlovian method'; and in 1955, Dr. Julia Starkiewicz went to Paris on a WHO scholarship, for a four-month course in social pediatrics. ${ }^{102}$

\section{The (partial) awakening}

In March 1956, shortly after Nikita Khrushchev's unexpected denunciation of Stalin at the $20^{\text {th }}$ Congress of the Communist Party of the Soviet Union (CPSU), Bolesław Bierut, the Stalinist hardliner in charge of People's Republic of Poland, died suddenly in Moscow. In June, there was a workers' insurrection in Poznań. In October, Władysław Gomułka, Bierut’s opponent imprisoned in 1951 for "right-wing nationalist deviation", was elected the PUWP's First Secretary without Khrushchev's former knowledge and approval. Poland stood on the brink of Soviet military intervention, and yet, unlike Hungary a month later, managed to avoid the bloodshed. Khrushchev conceded to Poland's turn towards a more 'nationalized' communism, and Poland began "a transformation from a Soviet Empire's colony into a dominion" 103 . The Thaw started.

On 11 April 1956, PUM's Faculty Council gathered at an extraordinary meeting devoted solely to "the analysis of the $20^{\text {th }}$ Congress of the CPSU"; Khrushchev's "Secret Speech" was discussed. This in itself

\footnotetext{
98 Czesław Murczyński, Radiologia Kliniczna, 3 vols. (Warszawa: PZWL 1950-1952).

99 Józef Taniewski, Zarys audiologii (Warszawa: PZWL, 1951).

100 Adam Krechowiecki, Zarys anatomii człowieka. Kompendium dla studentów i lekarzy (Warszawa: PZWL, 1958).

101 Dean Murczyński’s communication, 15 February 1950, FCM 1950, sign. A109. PUM Archives.

102 Dziesięciolecie, 24, 31, 45.

103 Raymond Pearson, "Polish October, Hungarian November," in The Rise and Fall of the Soviet Empire, $2^{\text {nd }}$ ed. (Houndsmill Basingstoke, Hampshire: Palgrave Macmillan, 2002), 58-60.
} 
was by no means a sign of the professors' sudden recovery from the previous state of overwhelming intimidation. Thousands of similar meetings were encouraged by the Party throughout the country, and PUWP's representatives were among the most active denunciators of Stalinist "errors and deviations". 104 That the atmosphere at PUM changed, however, can be seen in the protocols of the meeting. Members of Faculty spoke openly about "the pernicious effect the absence of constructive criticism had on science, on the examples of Lysenko and Lepeshiskaya"; how "Marxist science should not be called the only true one, otherwise it turns into a religion"; and that "betrayals and deviations resulted not only from the cult of personality, but also from excessive centralism, careerism, and fawning". 105 In mid-June, Rector Jarema informed the Faculty about changes to be expected in the legal rules concerning higher education. ${ }^{106}$ Indeed, the new act was passed in September, reversing the Soviet-style order introduced in 1951, and restoring the academic institutions' right to elect their governing bodies. ${ }^{107}$ On 17 October 1956, PUM's Senate and Faculty Council held the first elections in the school's history; Bolesław Górnicki (chair of Pediatrics since 1951) became the Rector, and Adam Krechowiecki was elected for Dean. In the third volume of PUM's Annals, printed in 1957, these events, on both local and national levels, were called "the Polish October Revolution". 108

The feeling of liberation was short-lived, and the Gomułka's Thaw soon transformed into a period of "small stabilization", with everyday life's hardships less overwhelming than in the Stalinist times, but still very much there. Central government's control over higher education institutions, though not as suffocating as previously, was nevertheless maintained. For PUM, however, some things did change for better, and significantly so. Prof. Zajączek became the member of Polish Sejm, and he presided over the Parliamentary Healthcare Commission. Through better connections

\footnotetext{
104 Paweł Machcewicz, "Social Protest and Political Crisis in 1956," in Stalinism in Poland, 99-118.

105 Discussion, 11 April 1956, FCM 1956, sign. A115. PUM Archives.

106 Rector Jarema's communication on the rectors' conference at the Ministry of Health, 13 June 1956, ibid.

107 Act of 10 September 1956 on changes to the Act on higher education and workers of science, Dziennik Ustaw 1956 no 41, item 185, http://isap.sejm.gov.pl/isap.nsf/ DocDetails.xsp?id=WDU19560410185.

108 “Kronika”, Rocznik Pomorskiej Akademii Medycznej 3 (1957), 24.
} 
with the state's decisional and executive center (via Zajączek, but also via Rector Górnicki, who proved to be a talented diplomat) the flow of funds for infrastructural investments increased slowly, but steadily. In the years 1957-1966, a number of clinics opened in the hospital complex at Pomorzany, some newly established, and some moved from PSK1, where space was made for the remaining units to expand. The number of assistant posts grew, too, thus making the production and circulation of knowledge easier, in sense of both didactics and research. Most importantly, the possibility to travel abroad improved exponentially. In the years 1956-1958, PUM's representatives took active part in twelve international conferences and congresses held in GDR, Czechoslovakia, Yugoslavia, and GDR, but also in France, Spain, Belgium, and England. In 1958 alone, ten persons went abroad to obtain specialist training unavailable locally. These study trips lasted from six weeks to three months, and their destinations included Moscow (radioisotope medicine), Erlangen (electrocardiology), Frankfurt am Mein (immunohistochemistry), Basel (pediatric metabolic disorders), Paris (bacteriology at Pasteur Institute), and Copenhagen (connective tissue pathology). ${ }^{109}$ Thus, PUM made first relevant connections with international scientific networks. However, the road to actual self-determination of how, where, and with whom the school made connections was long and winding. PUM had to wait for the collapse of state socialism, and Poland's accession to the European Union, to be fully in charge of the directions, forms, and quality of its participation in the production and circulation of relevant medical knowledge.

\section{Pomerānijas Medicīnas universitātes centieni apvienot zināšanu aprites tīklu Aukstā kara pirmsatkušṇa laikā (1948-1956)}

\section{Kopsavilkums}

Šì publikācija ir situācijas analīze, kurā aplūkots, ar kādām grūtībām bija jāsaskaras jaunizveidotajai medicīnas skolai, kad tā mēǵināja iekḷauties pastāvošajā zināšanu aprites tīklā stạ̣inisma periodā, par piemēru

109 “Wyjazdy naukowe,” Roczniki Pomorskiej Akademii Medycznej 5 (1959), 15-16. 
ņemot 1948. gadā dibināto Pomerānijas Medicīnas universitāti Ščecinā. Balstoties uz Pomerānijas Medicīnas universitātes arhīvā esošo dokumentu izpēti, kas saglabājušies par laika posmu no 1948. līdz 1956. gadam, publikācijā tiek analizēts, vai un cik daudz skola spēja nodrošināt atbilstību vairākiem kritērijiem, kuriem bija būtiska nozīme, lai varētu kḷūt par nozīmīgu zināšanu tīkla krustpunktu, īpaši pārrobežu un starptautiskā kontekstā. Šie kritēriji ir: piekḷuve attiecīgajai infrastruktūrai un resursiem; kvalificēts personāls, kas vēlas un spēj radīt zināšanas un dalīties ar tām; pietiekama autonomija lēmumu pieņemšanā; atbalsts no varas centriem; sakari ar esošajiem tīkliem.

Ščecinas statuss Polijā un Eiropā pēc 1945. gada ir izcelts kā būtisks faktors, kas ietekmēja Staḷina valdības nevēlēšanos risināt Pomerānijas Medicīnas universitātes akūto infrastruktūras un personāla deficītu un vienlaikus tās gatavību izmantot Pomerānijas Medicīnas universitāti kā politiskās propagandas instrumentu.

Atslēgvārdi: Pomerānijas Medicīnas universitāte, zināšanu aprite, stalıinisms.

\section{Joanna Nieznanowska}

Medicīnas vēstures un medicīnas ētikas katedra, Pomerānijas Medicīnas universitāte, Polija /

Department of History of Medicine and Medical Ethics,

Pomeranian Medical University, Poland 